\title{
Thermal Comfort Zones for Starter Meat-Type Quails
}

\section{-Author(s)}

Sousa MS

Tinôco I de FF"

Amaral AG"'

Inoue KRA"

Barreto SL"

Savastano Jr $\mathrm{H}^{\prime}$

Souza CF"

Paula MO'N

School of Animal Science and Food Engineering, Universidade de São Paulo, Av. Duque de Caxias Norte, 225, Campus da USP CEP: 13635-900, Pirassununga, SP

" Universidade Federal de Viçosa, Centro de Ciências Agrárias, Departamento de Engenharia Agrícola e Departamento de Zootecnia, Av. PH Rolfs s/n, Campus Universitário, CEP: 36570-000, Viçosa, MG

III Universidade Federal do Mato Grosso, Centro de Ciências Agrárias, Departamento de Engenharia Agrícola, Av. Fernando Corrêa da Costa, n. 2367, Bairro Boa Esperança, CEP: 78060-900, Cuiabá, MT

iv Universidade Federal do Espírito Santo, Centro de Ciências Agrárias, Alto Universitário, s/n, Guararema, Caixa Postal 16, CEP: 29500-000, Alegre, ES

\section{Mail Address}

Corresponding author e-mail address: M. S. Souza

School of Animal Science and Food Engineering, Universidade de São Paulo, Av. Duque de Caxias Norte, 225, Campus da USP, CEP: 13635-900, Pirassununga, SP E-mail: mariluzoo@hotmail.com, holmersj@usp.br

\section{nKeywords}

Environment, Coturnix, performance, livability.

\section{ABSTRACT}

The objective of this study was to determine thermal comfort ranges, as evaluated by air temperature and black-glove temperature and humidity index (BGTHI), for starter meat-type quails. Nine hundred quails were randomly distributed into five environmental chambers. Each chamber was programmed to provide different temperatures weekly. The following thermal environments were provided: SC - severe cold, MC - moderate cold, TC - recommended comfort environment, $\mathrm{MH}$ - moderate heat, and $\mathrm{SH}$ - severe heat. The best live performance was obtained when quails were submitted to temperatures of 36-39 ${ }^{\circ} \mathrm{C}$ and $\mathrm{BGTHI}$ of $87.1 \pm 0.4$ and $91.4 \pm 0.6$ during the first week of rearing. Temperatures of $27-30^{\circ} \mathrm{C}$ and BGTHI of $75.8 \pm 0.4$ and $79.9 \pm$ 0.6 , during the second week, and temperature of $24^{\circ} \mathrm{C}$ and BGTHI of $70.8 \pm 0.5$ during the third week of rearing.

\section{INTRODUCTION}

Brazil quail production increased 19.8\% between 2010 and 2011, with 15,567 million birds. In Brazil, the quail flock in the mid-western region increased $34.4 \%, 19.6 \%$ in the southeastern region, and $9.2 \%$ in the northern region. On the other hand, the flock was reduced in $5.1 \%$ in the southern region, and in $2.2 \%$ in the northeastern region. The southeastern region houses $65.5 \%$ of the national flock, and the state of São Paulo 46.4\%, recording an increase of 24\% in 2011 relative to 2010 (IBGE, 2012).

Quails are susceptible to changes in environmental temperature. Poultry in general have a thermoregulatory center in the central nervous system. The hypothalamus works as a physiological thermostat, controlling heat production and dissipation through several mechanisms, such as changing skin blood flow, as well as heart and respiratory rates (Moro, 1995).

Brazil has relatively high annual average temperatures of around 25 ${ }^{\circ} \mathrm{C}$. In some regions, maximum temperatures may reach $40{ }^{\circ} \mathrm{C}$, which may be detrimental to quail production. In addition, almost all quail production houses do not have the required environmental conditions, and quails are negatively affected by cold, particularly in the winter, and hot temperatures. The growth of quail production in Brazil, therefore, requires better knowledge on the effects of environmental temperatures on the performance of quails, as there are few studies on the thermal environment of these birds in the country.

The objective of this study was to determine thermal comfort ranges, as evaluated by air temperature and black-globe temperature and humidity index (BGTHI), for meat-type quails (Coturnix coturnix coturnix) during the starter rearing phase (1-21 days of age). 


\section{MATERIALS AND METHODS}

The experiment was carried out in five environmental chambers, measuring $2.5 \times 3.5 \times 2.5 \mathrm{~m}$, located in the Environment and Engineering of Agricultural System Research Center (Núcleo de Pesquisa em Ambiência e Engenharia de Sistemas Agroindustriais, AMBIAGRO) of Universidade Federal de Viçosa. Data were collected between January and February of 2012, totaling three experimental weeks (21 days).

Each environmental chamber was equipped with an electrical air heater (power of 2000 Watts), a hot/cold split air conditioner (1200 BTU/h), and an air humidifier (4.5 L capacity and average fog volume of $300 \mathrm{~mL} / \mathrm{h}$ ). An electronic temperature and humidity controller was used to control the heater and the humidifier.

In total, 900 one-day-old meat-type quails (Coturnix coturnix coturnix) of both sexes, with uniform body weight, and derived from the same breeder farm, were used. Quails were randomly distributed into the five environmental chambers, totaling 180 birds per treatment. Birds were distributed into five treatments, consisting of each environmental chamber providing different thermal environments, with six replicates (cages) of 30 birds each. Cages were 1.0- $\mathrm{m}$ wide $\times 0.5$ $\mathrm{m}$ deep $\times 0.5-\mathrm{m}$ high $\left(0.5 \mathrm{~m}^{2}\right)$ with a capacity of 166.6 $\mathrm{cm}^{2} / \mathrm{bird}$.

Studies have demonstrated that the thermal requirements of domestic poultry change as they grow, and based on this assumption, five different thermal condition ranges were defined for the three first week of life of the quails. One of these ranges was the thermal comfort range, as suggested by Albino \& Neme (1998), and the other four ranges were divided in two cold stress (moderate and severe) and two heat stress (moderate and severe) environments. Table 1 shows the different temperatures applied in each of these environments.

Table 1 - Thermal environments (treatments) applied during the three first rearing weeks.

\begin{tabular}{lccc}
\hline & $\begin{array}{c}\text { Temperature } \\
{ }^{\circ} \mathrm{C} \\
\text { week } \\
1\end{array}$ & $\begin{array}{c}\text { Temperature } \\
{ }^{\circ} \mathrm{C} \\
\text { week } \\
2\end{array}$ & $\begin{array}{c}\text { Temperature } \\
{ }^{\circ} \mathrm{C} \\
\text { week } \\
3\end{array}$ \\
\hline Severe cold (SC) & 30 & 27 & 24 \\
\hline Moderate cold (MC) & 33 & 30 & 27 \\
\hline Thermal comfort (TC) & 36 & 33 & 30 \\
\hline Moderate heat (MH) & 39 & 36 & 33 \\
\hline Severe heat (SH) & 42 & 39 & 36 \\
\hline
\end{tabular}

Air relative humidity was maintained at 55\% ( $\pm 5 \%)$ during the entire experimental period in all treatments, as recommended by Tinôco (2004) and Medeiros (2005). Temperature and relative humidity values were maintained constant during the entire experimental period, i.e., $24 \mathrm{~h}$ daily.

Birds were fed a starter diet, as recommended by Silva \& Costa (2009). Feed composition and feedstuff nutritional values used for feed formulation were determined according to Rostagno et al. (2011). All birds received the same feed supplied ad libitum. Feed was supplied at 08:00 and 16:00 $\mathrm{h}$ in order to maintain feeders full.

A continuous lighting program was adopted, of one hour of dark and 23 hours of light, during the entire experimental period, according to the standard applied in commercial farms.

In order to determine live performance, weight gain (WG) in $\mathrm{g}$, feed intake (FI) in $\mathrm{g}$, and feed efficiency (calculated as FE = weight gain in $\mathrm{g} /$ feed intake in $\mathrm{g}$ ), and livability (number of live birds divided by the total number of birds divided by 100 , expressed as \%) were weekly recorded.

Temperature and air relative humidity inside each environmental chamber were controlled using humidifiers, heaters, air-conditioning, and exhaustion fans. Data loggers with $0.1^{\circ} \mathrm{C}$ resolution were used to record temperature and air relative humidity. Environmental parameters were recorded every five minutes.

Based on the recorded values, black-globe temperature and humidity index (BGTHI) was calculated for each thermal environment according to the equation of Buffington et al. (1981).

Air renovation of the environmental chambers was carried out using two automatically activated axial exhaustion fans, allowing four air renovations per hour during the entire experimental period to maintain good air quality.

The obtained data were submitted to analysis of variance and means were compared by the test of Dunnett at $5 \%$ probability level. The thermal control environment (TC) was considered as the control treatment. Data were analyzed using the statistical package SAEG (Program Analysis for System Statistics and Genetics), developed by the Federal University of Viçosa (1999).

\section{RESULTS AND DISCUSSION}

The parameters temperature, air relative humidity, and black-globe temperature and humidity index were 
evaluated to determine the internal environment of the chambers.

Average temperature and air relative humidity, and respective $\mathrm{BGTH}$ values obtained in each chamber during the experimental period are presented in Table 2 .

Table 2 - Means and standard deviations of air temperature $(\mathrm{Ta})$, relative humidity $(\mathrm{RH})$, and black-globe temperature and humidity index (BGTHI) obtained weekly during the first three weeks of life of the studied quails.

\begin{tabular}{lccc}
\hline Thermal environment & $\mathrm{Ta}\left({ }^{\circ} \mathrm{C}\right)$ & $\mathrm{RH}(\%)$ & $\mathrm{BGTH}$ \\
\hline Week 1 $(1-7$ days) & & & \\
\hline Severe cold (SC) & $30.1 \pm 0.6$ & $56.9 \pm 5.1$ & $79.3 \pm 0.6$ \\
\hline Moderate cold (MC) & $33.0 \pm 0.8$ & $56.9 \pm 4.8$ & $83.3 \pm 0.7$ \\
\hline Thermal comfort (TC) & $36 \pm 0.6$ & $55.5 \pm 4.6$ & $87.1 \pm 0.4$ \\
\hline Moderate heat (MH) & $39.1 \pm 0.6$ & $55.8 \pm 6.3$ & $91.4 \pm 0.6$ \\
\hline Severe heat (SH) & $41.9 \pm 0.8$ & $56.5 \pm 5.8$ & $95.4 \pm 0.6$ \\
\hline Week 2 (8-14 days) & & & \\
\hline Severe cold (SC) & $27.4 \pm 0.4$ & $58.4 \pm 4.9$ & $75.8 \pm 0.4$ \\
\hline Moderate cold (MC) & $30.2 \pm 0.9$ & $59.9 \pm 6.1$ & $79.9 \pm 0.6$ \\
\hline Thermal comfort (TC) & $33.3 \pm 0.7$ & $55.2 \pm 4.5$ & $83.4 \pm 0.4$ \\
\hline Moderate heat (MH) & $35.8 \pm 1.3$ & $54.8 \pm 3.0$ & $86.7 \pm 0.7$ \\
\hline Severe heat (SH) & $39.1 \pm 0.6$ & $55.1 \pm 5.4$ & $91.2 \pm 1.0$ \\
\hline Week 3 (15-21 days) & & & \\
\hline Severe cold (SC) & $23.8 \pm 0.8$ & $58.5 \pm 5.9$ & $70.8 \pm 0.5$ \\
\hline Moderate cold (MC) & $26.8 \pm 0.7$ & $59.7 \pm 6.9$ & $75.2 \pm 0.6$ \\
\hline Thermal comfort (TC) & $30.0 \pm 0.9$ & $58.0 \pm 5.9$ & $79.4 \pm 0.5$ \\
\hline Moderate heat (MH) & $32.9 \pm 0.7$ & $57.9 \pm 4.7$ & $83.3 \pm 0.7$ \\
\hline Severe heat (SH) & $35.8 \pm 0.5$ & $59.1 \pm 4.4$ & $87.6 \pm 0.8$ \\
\hline & & & \\
\hline
\end{tabular}

The recorded temperature and air relative humidity values were close to those proposed for each thermal environment in the methodology (Table 2), indicating that there was adequate control of the thermal environment of the chambers.

To date, no BGTHI values specific for meat-type quails were published in literature. Therefore, the values obtained in the present study were compared with data obtained in broilers, as these data are available in literature. We believe that the current data could be used as the foundation of a data base for future evaluations of thermal comfort of quails based on BGTHI.

Oliveira et al. (2006) observed that BGTHI comfort values for broilers are in the range of $81.3 \pm 0.31$ in the first week of life, approximately 77 in the second week, and $74.9 \pm 1.65$ in the third week. It may be inferred that, in the case of quails, those values correspond to severe cold. Santos et al. (2002) assumed that minimum BGTHI limits before causing cold stress are 78.6 in the first week of life, 67.4 in the second week, and 65.0 between the third and sixth week. Therefore, it may be assumed that the quails submitted to moderate $(\mathrm{MH})$ and severe heat stress $(\mathrm{SH})$ suffered most, as their environmental limits were relatively outside the optimal BGTHI ranges for broilers according to each age group. However, in order to determine if thermal comfort BGTHI values are the same for broilers and for quails, live performance must be evaluated.

Table 3 shows mean body weight on day 7, feed intake, feed efficiency, and livability values of individual quails between one and seven days of age. As shown in Table 3, only body weight on day 1 was not statistically different among treatments $(p \geq 0.05)$. This indicates that initial body weight was uniform, precluding any possible effect of initial body weight on any of the evaluated performance parameters.

Feed intake, weight gain, feed efficiency, and livability determined in 7-d-old quails were significantly different $(p \leq 0.05)$ between thermal stress and control treatments.

The quails housed in the $\mathrm{SH}$ environment $\left(42{ }^{\circ} \mathrm{C}\right)$ presented $10.28 \%$ lower body weight at seven days of age $(29.28 \mathrm{~g})$ than those housed in the TC environment $\left(36^{\circ} \mathrm{C}\right)$ because BGTHI values was extremely high, impairing the performance of those birds. These results are consistent with those obtained by Van der Hel et al. (1991), who observed that the exposure of day-old

Table 3 - Body weight gain at day 7, feed intake (FI), weight gain (WG), feed efficiency (FI), and livability (LIV) of one- to seven-d-old quails and black-globe temperature and humidity index (BGTHI) as a function of thermal environments.

\begin{tabular}{lllllll}
\hline $\begin{array}{l}\text { Thermal } \\
\text { environment } \\
\left({ }^{\circ} \mathrm{C}\right)\end{array}$ & BW d7 (g) & FI (g/bird) & WG (g/bird) & FE & LIV (\%) & BGTHI \\
\hline $\mathrm{SC}-30$ & $33.21 \mathrm{a}$ & $40.31 \mathrm{a}$ & $24.12 \mathrm{a}$ & $0.60 \mathrm{a}$ & $76.11 \mathrm{a}$ & $79.3 \pm 0.6$ \\
\hline $\mathrm{MC}-33$ & $32.75 \mathrm{a}$ & $38.90 \mathrm{a}$ & $23.45 \mathrm{a}$ & $0.60 \mathrm{a}$ & $88.89 \mathrm{a}$ & $83.3 \pm 0.7$ \\
\hline $\mathrm{TC}-36$ & $31.50 \mathrm{a}$ & $37.69 \mathrm{a}$ & $22.37 \mathrm{a}$ & $0.59 \mathrm{a}$ & $97.78 \mathrm{~b}$ & $87.1 \pm 0.4$ \\
\hline $\mathrm{MH}-39$ & $32.56 \mathrm{a}$ & $28.72 \mathrm{~b}$ & $23.31 \mathrm{a}$ & $0.81 \mathrm{~b}$ & $97.22 \mathrm{~b}$ & $91.4 \pm 0.6$ \\
\hline $\mathrm{SH}-42$ & $29.28 \mathrm{~b}$ & $34.08 \mathrm{a}$ & $20.07 \mathrm{~b}$ & $0.59 \mathrm{a}$ & $96.11 \mathrm{~b}$ & $95.4 \pm 0.6$ \\
\hline
\end{tabular}

SC: severe cold; MC: moderate cold; TC: thermal comfort (control environment); SH: severe heat; MH: moderate heat. Means followed by different letters in the same column are different from the control treatment at $5 \%$ probability level by the test of Dunnett. 
chicks to high temperatures reduced weight gain. In another study, those authors verified that the exposure of chicks to high temperatures during the first week of life causes weight loss. Grieser et al. (2012), studying the weekly growth and development of meat-type quails between one and 42 days of age reared at temperatures between 30 and $32{ }^{\circ} \mathrm{C}$, obtained 22.59 $g$ weight gain.

The quails maintained in the $\mathrm{SC}\left(30^{\circ} \mathrm{C}\right)$ and $\mathrm{MC}(33$ ${ }^{\circ} \mathrm{C}$ ) environments had higher feed intake compared to those housed in $\mathrm{TC}\left(36^{\circ} \mathrm{C}\right)$. Despite not significant, the quails in treatments $\mathrm{SC}\left(30^{\circ} \mathrm{C}\right)$ and $\mathrm{MC}\left(33^{\circ} \mathrm{C}\right)$ presented $6.95 \%$ and $3.21 \mathrm{~T}$ higher feed intake, respectively, than those in the $\mathrm{TC}\left(36^{\circ} \mathrm{C}\right)$ treatment. It may be inferred that quails housed in cold environments used only net energy for maintenance, and that this energy was more efficient for the maintenance of homeothermy due to heat storage and conservation. Consequently, their weight gains were similar to that obtained in TC $\left(36^{\circ} \mathrm{C}\right)$. Therefore, quails reared in cold environments may present the same weight gains as those reared in thermal comfort. However, when achieving their physical limit, feed conversion ratio worsens. Quails in $\mathrm{TC}\left(36^{\circ} \mathrm{C}\right)$ loss heat by sensitive heat loss processes, with no energy expenditure.

The results of the present study also show that quails submitted to heat stress tend to reduce their voluntary feed intake in an attempt to reduce heat increment, expending energy for thermoregulation. Silva et al. (2012), evaluating the nutritional requirements of quails, found that quails, as other poultry species, modulate their feed intake as a function of environmental temperature.

Otutumi et al. (2010) verified that meat-type quails reared at $30^{\circ} \mathrm{C}$ had a feed intake of $39.04 \mathrm{~g}$ during the same period evaluated in the present experiment (1-7 days of age).In 2009, the same authors, evaluating the performance of meat-type quails maintained at a maximum temperature of $26.5^{\circ} \mathrm{C}$, obtained $39.84 \mathrm{~g} /$ bird/period for feed intake and $22.92 \mathrm{~g} / \mathrm{bird} /$ period for weight gain, which are close to the values determined in the present study in birds in the $\mathrm{SC}\left(30^{\circ} \mathrm{C}\right)$ and $\mathrm{MC}$ $\left(30^{\circ} \mathrm{C}\right)$ treatments.

The feed intake results of quails in the $\mathrm{MC}\left(33^{\circ} \mathrm{C}\right)$ and $\mathrm{TC}\left(36^{\circ} \mathrm{C}\right)$ groups are consistent with the findings of Grieser (2012), who evaluated the performance of 1- to 42-d-old quails weekly and obtained $38.90 \mathrm{~g} /$ bird/week, which value is the equal to that found for the MC group.

Environmental temperature also influenced feed efficiency, $(p \geq 0.05)$, with better value obtained in quails of the $\mathrm{MH}$ environment compared to those of the TC group. This may be explained by the lower feed intake of the $\mathrm{MH}$ group ( $28.72 \mathrm{~g} / \mathrm{bird} /$ period). Birds attempted to maintain their body temperature within the limits of homeothermy by reducing feed intake, and therefore, the production of body heat. These values are also linked to the high BGTHI values in the $\mathrm{MH}$ treatment.

As shown in Table 3, the TC environment (36 $\left.{ }^{\circ} \mathrm{C}\right)$ promoted high livability $(97.78 \%)$, whereas the SC $\left(30^{\circ} \mathrm{C}\right)$ and $M C\left(33^{\circ} \mathrm{C}\right)$ environments resulted in lower livability values. The quails reared at low temperatures during the first week of life needed to adjust their physiology to try to maintain constant body temperature, but some failed, resulting in the higher mortality observed in the cold environment groups.

The $\mathrm{BGTHI}$ values of these two treatments were lower than that of treatment $\mathrm{TC}\left(36^{\circ} \mathrm{C}\right)$, demonstrating that the best $B G T H I$ value for quails during the first week of rearing is $87.1 \pm 0.4$. The opposite happened with quails maintained in the $\mathrm{MH}\left(39^{\circ} \mathrm{C}\right)$ and $\mathrm{SH}(42$ ${ }^{\circ} \mathrm{C}$ ) environments. The obtained average livability values demonstrate that homeothermal animals, specifically meat-type quails, suffer with low temperatures in the first days of life, possibly because their thermoregulatory system is not fully developed yet. The results also show that young quails (starter phase) tolerate heat stress better than cold stress. This finding is consistent with May \& Lott (2000), who worked with temperatures of $28-32{ }^{\circ} \mathrm{C}$ in broilers during the first seven days of life and observed that lower temperatures resulted in higher mortality.

Based on the performance associated to BGTHI and livability results of the present experiment, as shown in Table 3, the $\mathrm{TC}\left(36^{\circ} \mathrm{C}\right)$ and $\mathrm{MH}\left(39^{\circ} \mathrm{C}\right)$ environments promoted thermal comfort for 1 - to 7 -d-old quails.

During the second experimental week, significant feed intake and weight gain differences $(p \leq 0.05)$ when hot and cold environments were compared with the recommended thermal comfort environment. However, treatments had no influence $(p \geq 0.05)$ on body weight at 14 days of age, feed efficiency, or livability.

Quails housed in cold environments (SC and MC) presented higher feed intake (Table 4). This indicates they increased their feed intake to utilize net energy for maintaining homeothermy (maintenance) rather than for body growth. However, their feed intake was sufficient to promote relatively higher weight gain than those housed in the $\mathrm{TC}\left(33^{\circ} \mathrm{C}\right)$ environment. On the other hand, the quails housed in the $\mathrm{MH}\left(36^{\circ} \mathrm{C}\right)$ 
Table 4 - Body weight gain on day 14, feed intake (FI), weight gain (WG), feed efficiency (FI), and livability (LIV) of 8- to 17-d-old quails and black-globe temperature and humidity index (BGTHI) as a function of thermal environments.

\begin{tabular}{lcccccc}
\hline Thermal environment $\left({ }^{\circ} \mathrm{C}\right)$ & $\mathrm{BW} 14 \mathrm{~d}$ & $\mathrm{Fl}(\mathrm{g} / \mathrm{bird})$ & WG $(\mathrm{g} / \mathrm{bird})$ & $\mathrm{FE}$ & LIV $(\%)$ & BGTHI \\
\hline $\mathrm{SC}-27$ & 74.48 & $95.56 \mathrm{~b}$ & $41.27 \mathrm{a}$ & 0.43 & 94.02 & $75.8 \pm 0.4$ \\
\hline $\mathrm{MC}-30$ & 73.92 & $89.69 \mathrm{~b}$ & $41.17 \mathrm{a}$ & 0.46 & 94.50 & $79.9 \pm 0.6$ \\
\hline $\mathrm{TC}-33$ & 68.77 & $83.65 \mathrm{a}$ & $37.27 \mathrm{a}$ & 0.45 & 96.05 & $83.4 \pm 0.4$ \\
\hline $\mathrm{MH}-36$ & 62.67 & $66.99 \mathrm{~b}$ & $30.11 \mathrm{~b}$ & 0.45 & 93.57 & $86.7 \pm 0.7$ \\
\hline $\mathrm{SH}-39$ & 60.71 & $54.28 \mathrm{~b}$ & $31.42 \mathrm{~b}$ & 0.58 & 94.32 & $91.2 \pm 1.0$ \\
\hline
\end{tabular}

SC: severe cold; MC: moderate cold; TC: thermal comfort (control environment); SH: severe heat; MH: moderate heat. Means followed by different letters in the same column are different from the control treatment at $5 \%$ probability level by the test of Dunnett.

and $\mathrm{SH}\left(39^{\circ} \mathrm{C}\right)$ environments presented 19.92 and $35.11 \%$ lower feed intake compared with those in the control treatment (TC). This indicates that they reduced their voluntary feed intake to reduce heat increment, and therefore, presented lower weight gain and body weight on day 14. In addition, BGTHI values were higher in those two hot environments. Despite no physiological parameters were evaluated, it was observed that sensitive heat loss were not very efficient in the hot environments. Therefore, latent heat loss (evaporation) was more relevant in these birds. This mechanism of heat exchange produces only heat loss, which seemed to benefit the birds, as they do not present sweat glands. The hot environments caused heat stress, making quails exchange heat with the environment by panting (increased respiratory rate), which was observed during the experiment, in the attempt of maintaining homeothermy.

The feed intake values obtained in the $\mathrm{MH}$ (36 $\left.{ }^{\circ} \mathrm{C}\right)$ and $\mathrm{SH}\left(39^{\circ} \mathrm{C}\right)$ treatments are in agreement with the results of Lana et al. (2000). The authors found that, under high temperatures, broilers consume less feed and gain less weight, as function of lower feed intake, and that high BGTHI values cause worse broiler performance. Feed intake results of quails in the $\mathrm{MC}\left(33^{\circ} \mathrm{C}\right)$ and $\mathrm{TC}\left(36^{\circ} \mathrm{C}\right)$ groups, as also found in week 1 , are consistent with the findings of Grieser (2012), who weekly evaluated the performance of 1to 42 -d-old quails and obtained $89.36 \mathrm{~g} / \mathrm{bird} /$ week in those maintained at $29^{\circ} \mathrm{C}$.
Otutumi et al. (2009), working with meat-type quails between eight and 14 days of age housed at a maximum temperature of $26.5{ }^{\circ} \mathrm{C}$, obtained feed intake of $89.77 \mathrm{~g} / \mathrm{bird} /$ period and $39.23 \mathrm{~g} / \mathrm{bird} /$ period weight gain.

Based on the performance associated to BGTHI and livability results of the present experiment, as shown in Table 4, the SC $\left(27^{\circ} \mathrm{C}\right)$ and $\mathrm{MC}\left(30^{\circ} \mathrm{C}\right)$ environments promoted thermal comfort for 8- to 14-d-old quails.

Table 5 shows mean body weight on day 21, feed intake, feed efficiency, and livability values of individual quails between 15 and 21 days of age. As shown in Table 5, body weight at 21 days of age, feed intake, weight gain, and feed efficiency were significantly different $(p \leq 0.05)$ between thermal stress and control $(\mathrm{TC})$ treatments. Treatments did not affect livability $(\mathrm{p} \geq 0.05)$.

Quails of the SC $\left(24^{\circ} \mathrm{C}\right)$ and $\mathrm{MC}\left(27^{\circ} \mathrm{C}\right)$ presented 18.43 and $12.69 \%$ higher average body weight at 21 days of age $(\mathrm{g} / \mathrm{bird})$, respectively, than those of the TC $\left(30^{\circ} \mathrm{C}\right)$ treatment. Those birds also had higher weight gain due to their higher feed intake. Despite not statistically significant, quails housed in the SH (36 ${ }^{\circ} \mathrm{C}$ ) environment presented $2.93 \%$ lower body weight at 21 days than those in the $\mathrm{TC}\left(30^{\circ} \mathrm{C}\right)$ treatment. The high $\mathrm{BGTHI}$ value resulted in worse performance. Côrrea et al. (2007), evaluating different crude protein requirements - but using the same as in the present experiment - for grower meat-type quails, obtained $113.94 \mathrm{~g} / \mathrm{bird}, 105.82 \mathrm{~g} / \mathrm{bird}$ and $234.29 \mathrm{~g} / \mathrm{bird}$ for

Table 5 - Body weight gain on day 21, feed intake (FI), weight gain (WG), feed efficiency (FI), and livability (LIV) of 15- to 21-d-old quails and black-globe temperature and humidity index (BGTHI) as a function of thermal environments.

\begin{tabular}{lllllll}
\hline Thermal environment $\left({ }^{\circ} \mathrm{C}\right)$ & $\mathrm{BW} \mathrm{d21}(\mathrm{g})$ & $\mathrm{FI}(\mathrm{g} / \mathrm{bird})$ & WG $(\mathrm{g} / \mathrm{bird})$ & $\mathrm{FE}$ & $\mathrm{LIV}(\%)$ & $\mathrm{BGTHI}$ \\
\hline $\mathrm{SC}-24$ & $121.60 \mathrm{~b}$ & $127.37 \mathrm{~b}$ & $49.71 \mathrm{~b}$ & $0.40 \mathrm{a}$ & 96.41 & $70.8 \pm 0.5$ \\
\hline $\mathrm{MC}-27$ & $115.71 \mathrm{~b}$ & $109.53 \mathrm{~b}$ & $41.79 \mathrm{a}$ & $0.38 \mathrm{a}$ & 96.77 & $75.2 \pm 0.6$ \\
\hline $\mathrm{TC}-30$ & $102.68 \mathrm{a}$ & $90.26 \mathrm{a}$ & $33.33 \mathrm{a}$ & $0.37 \mathrm{a}$ & 96.99 & $79.4 \pm 0.5$ \\
\hline $\mathrm{MH}-33$ & $103.64 \mathrm{a}$ & $89.92 \mathrm{a}$ & $40.96 \mathrm{a}$ & $0.46 \mathrm{a}$ & 93.97 & $83.3 \pm 0.7$ \\
\hline $\mathrm{SH}-36$ & $99.67 \mathrm{a}$ & $62.47 \mathrm{~b}$ & $41.23 \mathrm{a}$ & $0.66 \mathrm{~b}$ & 94.43 & $87.6 \pm 0.8$ \\
\hline
\end{tabular}

SC: severe cold; MC: moderate cold; TC: thermal comfort (control environment); SH: severe heat; MH: moderate heat. Means followed by different letters in the same column are different from the control treatment at $5 \%$ probability level by the test of Dunnett. 
body weight at 21 days of age, weight gain, and feed intake, respectively.

Similarly to body weight at 21 of age, birds in the SC $\left(24^{\circ} \mathrm{C}\right)$ and $\mathrm{MC}\left(27^{\circ} \mathrm{C}\right)$ groups presented $41.11 \%$ and $21.35 \%$ higher feed intake than those in the control group $\left(\mathrm{TC}, 30^{\circ} \mathrm{C}\right)$. The quails housed in the cold environments increased their metabolic rate to increase heat production; therefore, their maintenance requirements increased and birds consumed more feed to supply these new maintenance requirements, essential for their survival. On the other hand SH (36 ${ }^{\circ} \mathrm{C}$ ) quails had $30.79 \%$ lower feed intake than those housed in the control environment. Nascimento e Silva (2010) highlighted that one of the effects of heat stress that causes significant losses is the reduction in feed intake, as birds try to reduce body heat production by reducing dietary energy intake. Both digestion and nutrient absorption generate energy, which is called heat increment when it is released.

Under cold stress, growing animals maintain their feed intake, generating heat increment, and most of the energy that would be used for tissue accretion is utilized for maintenance, worsening performance. This influences bird growth in the subsequent rearing phases, resulting lower productivity, lack of flock uniformity, weight loss, and worse feed conversion ratio (Almeida, 2010).

Relative to weight gain during this period, only the SC $\left(24^{\circ} \mathrm{C}\right)$ was significantly different $(p \leq 0.05)$ from the control group $\left(\mathrm{TC}, 30^{\circ} \mathrm{C}\right)$, with $49.14 \%$ higher weight gain.

Based on the results presented in Table 5, it is inferred that SC $\left(24^{\circ} \mathrm{C}\right)$ thermal environment represented the thermal comfort of quails during the third week of rearing in terms of performance (body weight at 21 days of age, feed intake, and weight gain).

\section{CONCLUSIONS}

The thermal comfort temperature ranges for meattype quails in the first three weeks of life are: 36 to 39 ${ }^{\circ} \mathrm{C}$ and BGTHI values between $87.1 \pm 0.4$ and $91.4 \pm$ 0.6 during the first week; 27 to $30^{\circ} \mathrm{C}$ and BGTHI values between $75.8 \pm 0.4$ and $79.9 \pm 0.6$ during the second week, and $24^{\circ} \mathrm{C}$ and BGTHI of $70.8 \pm 0.5$ during the third week of rearing;

The best livability values were obtained in quails housed under thermal comfort $\left(36^{\circ} \mathrm{C}\right)$.

\section{REFERENCES}

Albino LFT, Neme R. Codorna: manual prático de criação. Viçosa, MG: Editora Aprenda Fácil; 1998. 56p.
Almeida EU. Níveis de lisina digestível e planos de nutrição para frangos de corte machos de 1 a 42 dias de idade [dissertação]. Boa Vista (ES): Centro Universitário de Vila Velha; 2010

Buffington DE, Collasso-Arocho A, Canton GH, Pitt D. Black globehumidity index $(\mathrm{BGHI})$ as comfort equation for dairy cows. Transaction of the ASAE $1981 ; 24(3): 711-714$

Cassuce DC. Determinação das faixas de conforto térmico para frangos de corte de diferentes idades criados no Brasil [tese]. Viçosa (MG): Universidade Federal de Viçosa; 2011

Côrrea GSS, Silva MA, Côrrea $A B$, et al. Exigências de proteína bruta para codornas de corte EV1 em crescimento. Arquivos Brasileiros de Medicina Veterinária e Zootecnia 2007;59(5):1278-1286.

Grieser DO. Estudo do crescimento e composição corporal de linhagens de codornas de corte e postura [mestrado]. Maringá (PR): Universidade Estadual de Maringá; 2012.

Instituto Brasileiro de Geografia e Estatística. Produção da pecuária municipal de 2011 [citado 2013 Jan 1]. Disponível em: http://www. ibge.gov.br

Lana GRQ, Rostagno HS, Albino LFT, Lana AMQ. Efeito da temperatura ambiente e restrição alimentar sobre o desempenho e a composição da carcaça de frangos de corte. Revista Brasileira de Zootecnia 2000;29(4):1117-1123

May JD, Lott BD. The Effect of Environmental Temperature on Growth and Feed Conversion of Broilers to 21 Days of Age. Poultry Science 2000;79:669-671.

Medeiros CM, Baêta FC, Oliveira RFM, Tinôco IFF, Albino LFT, Cecon PR. Efeitos da temperatura, umidade relativa e velocidade do ar em frangos de corte. Engenharia na Agricultura 2005;13(4): 277-286.

Moraes VMB, Ariki J. Importância da nutrição na criação de codornas de qualidades nutricionais do ovo e carne de codorna. Jaboticabal: Universidade Estadual Paulista; 2009. p.97-103.

Moro D. Sistemas de aquecimento em instalações avícolas na fase inicial. Anais do $1^{\circ}$ Simpósio Internacional De Ambiência E Instalações Na Avicultura Industrial; 1995; Campinas, São Paulo. Brasil: FACTA; 1995. p.139.

Nascimento ST, Silva IJO. As perdas de calor das aves: entendendo as trocas de calor com o meio [citado 2012 Dez 4]. Disponível em: http://www. avisite.com.br/cet/img/20100916_trocasdecalor.pdf. 2010

Oliveira RFM, Donzele JL, Abreu MLT, et al. Efeitos da temperatura e da umidade relativa sobre o desempenho e o rendimento de cortes nobres de frangos de corte de 1 a 49 dias de idade. Revista Brasileira de Zootecnia 2006;35(3):797-803.

Otutumi LK, Furlan AC, Martins EN, et al. Diferentes vias de administração de probiótico sobre o desempenho, rendimento de carcaça e a população microbiana do intestino delgado de codornas de corte. Revista Brasileira de Zootecnia 2010;39(1):158-164.

Otutumi LK, Furlan AC, Martins EN, et al. Efeito do probiótico sobre o desempenho, rendimento de carcaça e exigências nutricionais de proteína bruta de codornas de corte. Revista Brasileira de Zootecnia 2009;38(2):299-306.

Rostagno HS, Albino LFT, Donzele JL, et al. Tabelas brasileiras para aves e suínos: composição de alimentos e exigências nutricionais. 3. ed. Viçosa: UFV, DZO; 2011. 252p

Santos RC, Tinôco IFF, Paulo MO, Cordeiro MB, Silva JN. Análise de coberturas com telhas de barro e alumínio, utilizadas em instalações 
animais para duas distintas alturas de pé-direito. Revista Brasileira de Engenharia Agrícola e Ambiental 2002;6(1):142-146.

Silva JHV, Jordão Filho J, Perazzo FG et al. Exigências nutricionais de codornas. Revista Brasileira de Saúde Produção Animal 2012;13(3):775-790.

Silva VK, Silva JDT, Gravena RA, Marques RH, Hada FH, Moraes VMB. Desempenho de frangos de corte de 1 a 21 dias de idade alimentados com rações contendo extrato de leveduras e prebiótico e criados em diferentes temperaturas. Revista Brasileira de Zootecnia 2009;38(4): 690-696.

Silva JHV, Costa FGP. Tabelas para codornas japonesas e européias. $2^{\text {a }}$ ed. Jaboticabal: Ed. Funep; 2009. 107 p.
Tinôco IFF. A granja de frangos de corte. In: Mendes AA, Nääs Ide A, Macari M, editores. Produção de frangos de corte. Campinas: FACTA; 2004. $356 \mathrm{p}$

Universidade Federal De Viçosa. Sistema para análise estatística e genética. Versão 8.0. Viçosa: Fundação Arthur Bernardes; 1999.

Van Der Hel W, Verstergen MWA, Henken AM, et al. The upper critical temperature in neonatal chicks. Poultry Science 1991;70(9):18821887 
